\title{
Respon Fisiologis dan Metabolit Darah Kambing dan Domba yang Ditransportasi dengan Pick-Up Triple-Deck
}

Physiological Response and Blood Metabolites of Goat and Sheep Transported by Pick-Up Triple-Deck

\author{
R. A. Gopar ${ }^{1,4^{*}}$, R. Afnan ${ }^{2}$, S. Rahayu ${ }^{2}$, \& D. A. Astuti ${ }^{3}$ \\ ${ }^{1}$ Program Studi Ilmu Produksi dan Teknologi Peternakan, IPB University \\ ${ }^{2}$ Departemen Ilmu Produksi dan Teknologi Peternakan, Fakultas Peternakan, IPB University \\ ${ }^{3}$ Departemen Ilmu Nutrisi dan Teknologi Pakan, Fakultas Peternakan, IPB University, Jalan Agatis , Kampus \\ IPB Dramaga, Bogor 16680, Indonesia \\ ${ }^{4}$ Pusat Teknologi dan Produksi Pertanian, Badan Pengkajian dan Penerapan Teknologi (BPPT), \\ Gedung LAPTIAB Lt.2 Kawasan Puspiptek Serpong, Tangerang Selatan 15314. \\ *Corresponding author: ruslan.abdul@bppt.go.id \\ (Received 30-06-2020; Revised 25-07-2020; Accepted 06-08-2020)
}

\begin{abstract}
The overall transportation process is a gripping activity for goats and sheep. Goats and sheep can experience stress as reflected by indicators of weight loss, physiological responses and blood metabolites. The use of sheep goat and sheep conveyance according to the Regulation of the Minister of Agriculture of the Republic of Indonesia number 114/Permentan/PD.410/9/2014concerning the transportation of sacrificial animals, vehicles can be designed for a maximum of two decks. Farmers use pick-up vehicles arranged in three levels to reduce transportation costs. This study uses two triple-deck pick-up vehicles for 60 goats and 60 sheep. Each deck is filled with 20 animals and five animals are taken as samples. The design used by using a randomized block design (RBD), the position of the deck (deck 1, deck 2, deck 3) as a factor, and body weight as groups. The evaluation results of goat and sheep transportation with a distance of $\pm 674 \mathrm{~km}$ ( \pm 16 hours of travel) shows that deck has no significant effect $(\mathrm{P}>0.05)$ on the weight loss of goat and sheep also did not affect $(P>0.05)$ on the physiological response and blood metabolites. The stress level of goats and sheep transported is not affected by deck position.
\end{abstract}

Keywords: goat, sheep, transportation, triple-deck, physiology response

ABSTRAK

Proses transportasi secara keseluruhan merupakan kegiatan yang mencekam bagi kambing dan domba. Kambing dan domba dapat mengalami cekaman yang tercermin dari indikator penurunan berat badan, respons fisiologis dan metabolit darah. Penggunaan alat angkut kambing dan domba telah diatur dalam Peraturan Menteri Pertanian Republik Indonesia nomor 114/Permentan/PD.410/9 /2014 tentang Pemotongan Hewan Kurban pada pasal 9 bahwa alat angkut kambing dan domba dapat dirancang maksimal dua tingkat. Peternak menggunakan kendaraan pick-up yang diatur dalam tiga tingkat untuk mengurangi biaya transportasi. Penelitian ini menggunakan dua kendaraan pick-up triple-deck untuk 60 ekor kambing dan 60 ekor domba. Setiap deck diisi dengan 20 ternak dan lima ternak diambil sebagai sampel. Rancangan yang digunakan adalah rancangan acak kelompok (RAK) posisi deck (deck 1, deck 2, deck 3) sebagai faktor, dan bobot badan sebagai kelompok. Hasil evaluasi transportasi domba dan kambing dengan jarak $\pm 674 \mathrm{~km}( \pm 16$ jam perjalanan) menunjukkan bahwa deck tidak berpengaruh signifikan $(P>0.05)$ terhadap penurunan berat badan kambing dan domba, juga tidak mempengaruhi $(\mathbf{P}>\mathbf{0 . 0 5})$ respons fisiologis dan metabolit darah. Tingkat cekaman pada transportasi kambing dan domba tidak dipengaruhi oleh posisi deck.

Kata kunci: kambing, domba, transportasi, triple-deck, respon fisiologis 


\section{PENDAHULUAN}

Proses transportasi secara keseluruhan merupakan kegiatan yang mencekam bagi domba dan kambing. Proses transportasi meliputi pra loading, loading, travelling, unloading, dan post loading setelah ternak sampai di tujuan (CATGP 2017). Cekaman karena transportasi dapat memberikan perubahan pada sistem fisiologis dan homeostatis ternak sebagai indikator dari perkembangan reaksi cekaman selama dan sesudah transportasi (Siregar 2011). Domba dan kambing bisa mengalami cekaman yang tercermin dari indikator fisik, respon fisiologis (Nurmi 2016), kadar kimia darah dan hematologi. Secara fisik, efek dari transportasi ternak berpotensi mengakibatkan penyusutan seperti penurunan bobot badan, sakit, cedera bahkan kematian (Kassab dan Mohammed 2014).

Cekaman transportasi dipengaruhi oleh jarak tempuh, durasi perjalanan, jenis kendaraan, kondisi jalan, loading dan unloading, kecepatan kendaraan, dan kondisi lingkungan (Costa 2008; Fazio et al. 2018; Fisher et al. 2004). Jarak transportasi dan lama transportasi telah diidentifikasi sebagai potensi merugikan terhadap status kesejahteraan ternak, karena durasi paparan penyebab cekaman yang lebih lama terhadap ternak. Baihaqi et al. (2011) melakukan transportasi domba ekor gemuk selama \pm 30 jam dengan jarak $\pm 650 \mathrm{~km}$ menggunakan kendaraan truk yang dibagi tiga tingkat mengakibatkan penurunan bobot badan domba $8.3 \%$ pada domba ekor gemuk jantan dan $10.6 \%$ pada domba ekor gemuk betina.

Penggunaan alat angkut domba dan kambing telah diatur dalam Peraturan Menteri Pertanian Republik Indonesia nomor 114/Permentan/PD.410/9/2014 tentang Pemotongan Hewan Kurban pada pasal 9 bahwa alat angkut domba dan kambing dapat dirancang maksimal dua tingkat dengan ketinggian yang cukup untuk memungkinkan hewan dapat berdiri dengan normal. Jarak yang cukup jauh dan waktu tempuh lama membuat para penyedia bakalan membuat solusi untuk menekan biaya transpotasi dengan menggunakan kendaraan pick-up yang disusun dengan tiga tingkat (triple-deck) sehingga dapat mengangkut lebih banyak ternak. Pengangkutan dengan triple-deck diduga menimbulkan potensi cekaman dan ketidaknyamanan pada ternak berupa kelembapan lebih tinggi dan polusi terutama di deck paling bawah akibat akumulasi urin yang diturunkan dari ternak di atasnya.

Belum banyak penelitian yang memotret kondisi transportasi ternak ruminansia kecil yang dilakukan masyarakat, yang salah satunya adalah penggunaan kendaraan pick-up triple-deck. Bahkan belum ditemukan penelitian yang membahas tentang cekaman yang diakibatkan posisi deck pada ternak domba dan kambing di Indonesia.

Tujuan dari penelitan ini adalah mengkaji tingkat cekaman yang ditimbulkan oleh transportasi menggunakan pick-up triple-deck terhadap perubahan fisiologis, penyusutan bobot badan dan metabolit darah kambing dan domba yang ditransportasikan dari provinsi Jawa Timur menuju RPH terpadu kota Bogor $( \pm 674 \mathrm{~km})$.

\section{MATERI DAN METODE}

Domba dan kambing milik PT. Agro Apis Palacio digunakan dalam penelitian ini. Domba ekor gemuk berasal dari Desa Soco Kecamatan Bendo Kabupaten Magetan dan kambing peranakan etawah berasal dari Desa Jatisari, Kecamatan Geger, Kabupaten Madiun. Sebanyak 60 ekor domba ekor gemuk jantan dan 60 ekor kambing peranakan etawa jantan usia satu sampai dua tahun dengan bobot 30 sampai $35 \mathrm{~kg}$ diangkut menggunakan kendaraan yang berbeda. Setiap deck diisi 20 ekor ternak. Sample pengamatan diambil dari 5 ekor ternak pada tiap deck.

Dua mobil pick-up Mitsubishi L 300 dengan bak triple-deck berukuran panjang $218 \mathrm{~cm}$, lebar $148 \mathrm{~cm}$ (kepadatan $0.158 \mathrm{~m}^{2}$ ekor-1), dan tinggi tiap deck $40 \mathrm{~cm}$ digunakan untuk mengangkut ternak penelitian (Gambar 1). Ketinggian $40 \mathrm{~cm}$ didesain untuk ternak pada posisi berbaring selama dalam perjalanan, ini tidak sesuai dengan Permentan nomor 114/Permentan/PD.410/9/2014 yang mensyaratkan kendaraan di desian agar ternak bisa berdiri. Ternak ditransportasikan dari daerah asal menuju RPH Kota Bogor secara beriringan. Rute perjalanan melewati jalur tol dan non tol. Jalur tol masuk melalui pintu tol Ngawi

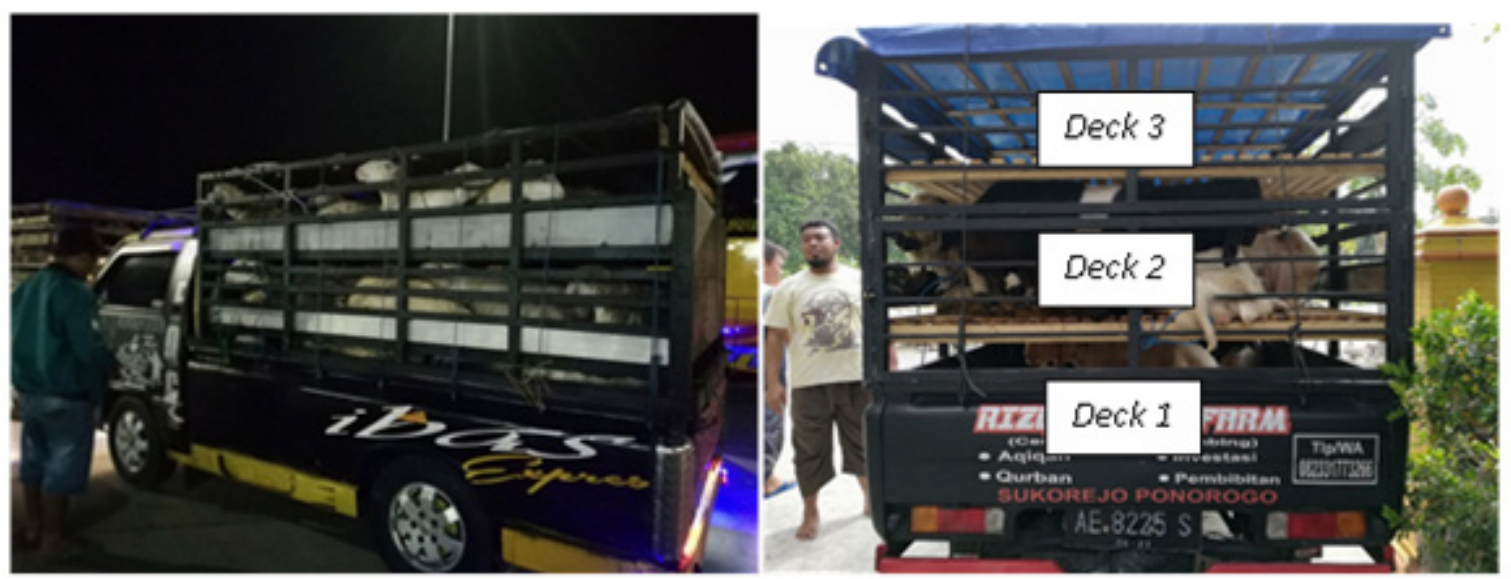

Gambar 1. Alat transportasi pick-up triple-deck 
dan keluar melalui tol lingkar luar Bogor sejauh \pm 624 $\mathrm{km}$. Sementara jarak non tol sekitar $\pm 50 \mathrm{~km}$. Kecepatan maksimal perjalanan di jalan tol adalah $80 \mathrm{~km} \mathrm{jam}^{-1}$, sementara di jalur non tol maksimal $40 \mathrm{~km} \mathrm{jam}^{-1}$. Durasi perjalanan keseluruhan sekitar 16 jam.

Alat pengukur status fisiologis ternak adalah termometer klinis digital dan stetoskop. Bobot badan diukur menggunakan timbangan gantung digital kapasitas $200 \mathrm{~kg}$ dengan ketelitian 50 g. Digital thermohumidity dan data logger digunakan untuk mengukur suhu dan kelembapan lingkungan

Alat digital thermohumidity dipasang satu unit dengan posisi di tengah bagian depan pada setiap deck untuk mengukur suhu $\left({ }^{\circ} \mathrm{C}\right)$ dan kelembapan udara $(\%)$. Pengukuran mikrolimatik dilakukan pada saat kondisi kendaraan kosong, saat sebelum berangkat, selama dalam perjalanan, dan saat tiba di tujuan. Suhu dan kelembapan udara digunakan untuk menentukan temperature humidity index (THI) berdasarkan formulasi Dikmen et al. (2008) dan Thompson dan Dahl (2012), yaitu:

$$
\begin{gathered}
T H I=(1.8 \times \mathrm{T}+32)-[(0.55-0.0055 \times \mathrm{RH}) \times(1.8 \times \mathrm{T} \\
-26)]
\end{gathered}
$$

Keterangan:

$$
\begin{array}{ll}
\text { THI } & =\text { Temperature Humidity Index } \\
\mathrm{T} & =\text { Suhu udara }\left({ }^{\circ} \mathrm{C}\right) \\
\mathrm{RH} & =\text { Kelembapan udara }(\%)
\end{array}
$$

Pengamatan status fisiologi, penimbangan dan Pengambilan sample darah kambing dan domba dilakukan sebelum transportasi dan setelah transportasi. Pengamatan respon fisiologi pada penelitian ini meliputi: frekuensi pernapasan (kali menit ${ }^{-1}$ ), detak jantung (kali menit ${ }^{-1}$ ), dan suhu rektal $\left({ }^{\circ} \mathbf{C}\right)$. Pengukuran frekuensi detak jantung diamati dengan menggunakan stetoskop yang ditempelkan pada bagian dada sebelah kiri selama 30 detik. Pengukuran laju respirasi diamati dengan cara menghitung frekuensi inspirasi dan ekspirasi dalam 30 detik. Suhu rektal diamati dengan memasukkan termometer klinis digital ke dalam rektum dan pembacaan dilakukan setelah suara alarm termometer klinis digital berbunyi (Gonzaga do Santos et al. 2019).

Sampel darah diambil menggunakan syringe $3 \mathrm{ml}$ melalui vena jugularis dari setiap ternak sampel. Sampel darah kemudian ditampung pada vacutube plain dan sentrifugasi selama 10 menit pada 3000 rpm untuk mendapatkan sampel serum. Serum kemudian disalurkan ke dalam tabung Eppendorf $1.5 \mathrm{ml}$ dan disimpan pada suhu $-20{ }^{\circ} \mathrm{C}$ (Kassab dan Mohammed 2014). Serum dianalisis menggunakan alat spektrofotometer untuk kadar glukosa $\left(\mathrm{mg} \mathrm{dl}{ }^{-1}\right)$ menggunakan kit nomor katalog 112191, blood urea nitrogen $(\mathrm{BUN})\left(\mathrm{mg} \mathrm{dl}^{-1}\right)$ menggunakan kit lengkap dengan nomor katalog 110491, kreatinin ( $\mathrm{mg} \mathrm{dl}^{-1}$ ) diukur menggunakan Metode Reaksi Jaffe (Sabarudin et al. 2012).

Pengamatan status fisiologi, penimbangan dan Pengambilan sample darah domba dan kambing dilakukan pada saat yang tidak bersamaan. Pengambilan data domba dilakukan pada sore hari pada pukul 14.30 WIB sampai pukul 16.00 WIB, kurang lebih 3 sampai 4 jam sebelum ternak dimuat ke dalam kendaraan. Pengambilan data setelah pengangkutan dilakukan 3 jam setelah ternak tiba di lokasi akibat kondisi di lapangan yang menunggu antrian bongkar. Pengambilan data kambing dilakukan pada saat akan dimuat ke dalam kendaraan, yaitu pukul 19.00 WIB sampai pukul 21.00 WIB. Pengambilan data setelah proses bongkar selesai sekitar pukul 14.30 WIB.

Rancangan menggunakan acak kelompok (RAK) menurut Gaspersz (1991) dengan posisi deck (deck 1, deck 2, deck 3) sebagai faktor perlakuan dan bobot badan sebagai kelompok. Data respon fisiologis, penyusutan bobot badan dan metabolit darah diuji ANOVA (analysis of variance) menggunakan program SPSS versi 25.0. Parameter THI dibahas secara deskriptif.

\section{HASIL DAN PEMBAHASAN}

\section{Temperature Humidity Index (THI)}

THI adalah parameter yang biasa digunakan untuk menggambarkan beban panas, yang merupakan satu nilai dari kombinasi suhu dan kelembapan lingkungan dan suatu indikator yang baik untuk mengukur cekaman yang diakibatkan oleh mikroklimatik (Qisthon dan Hartono 2019). Nilai $T H I$ ini menyajikan lima zona cekaman untuk hewan yaitu $<72$ tanpa cekaman, 72-78 cekaman ringan, 7889 cekaman berat, 89-98 cekaman sangat parah, $>98$ hewan mati (Koluman dan Daskiran 2011). Nilai THI normal jika $<74,75-78$ adalah status siaga, 79-83 status bahaya dan sangat berbahya apabila nilai $T H I>84$ (Hamdan et al. 2018).

Nilai THI menujukan selama perjalanan ternak mengalami cekaman ringan hingga berat pada seluruh deck yang diakibatkan oleh mikroklimatik. Rata-rata nilai THI untuk kambing deck $181.52 \pm 3.81$, deck $279.40 \pm 3.67$, dan deck $378.85 \pm 4.43$ (Gambar 2). Rata-rata nilai THI pada domba adalah deck $179.30 \pm 4.51$, deck $279.40 \pm$ 4.24, dan deck $377.95 \pm 4.77$ (Gambar 3). Nilai THI pada deck 3 menunjukan angka paling rendah dari semua deck baik pada angkutan kambing maupun domba, dan masuk dalam kategori cekaman siaga (Hamdan et al. 2018), atau cekaman ringan (Koluman dan Daskiran 2011). Pada deck 1 dan deck 2 masuk pada katagori bahaya (Hamdan et al. 2018) atau cekaman berat (Koluman dan Daskiran 2011). Vetilasi udara yang lebih terbuka diduga menjadi faktor penyebab tingkat cekaman yang lebih rendah pada deck 3 , sedangkan pada deck 1 dan deck 2 arah udara dari depan tertutup oleh kabin.

Respon Fisiologis dan Penyusutan Bobot Badan

Respon fisiologi dan penyusutan bobot badan kambing dan domba diperlihatkan pada Tabel 1. Analisis ragam menunjukan tidak ada pengaruh signifikan $(\mathrm{P}>0.05)$ perbedaan posisi deck terhadap perubahan suhu rektal, frekuensi detak jantung, laju respirasi, dan penyusutan bobot badan kambing dan domba.

Suhu rektal. Analisis ragam menunjukan secara umum posisi deck tidak berpengaruh nyata $(\mathrm{P}>0.05)$ terhadap peningkatan suhu rektal kambing. Rata-rata suhu rektal kambing penelitian masih dalam kondisi normal 


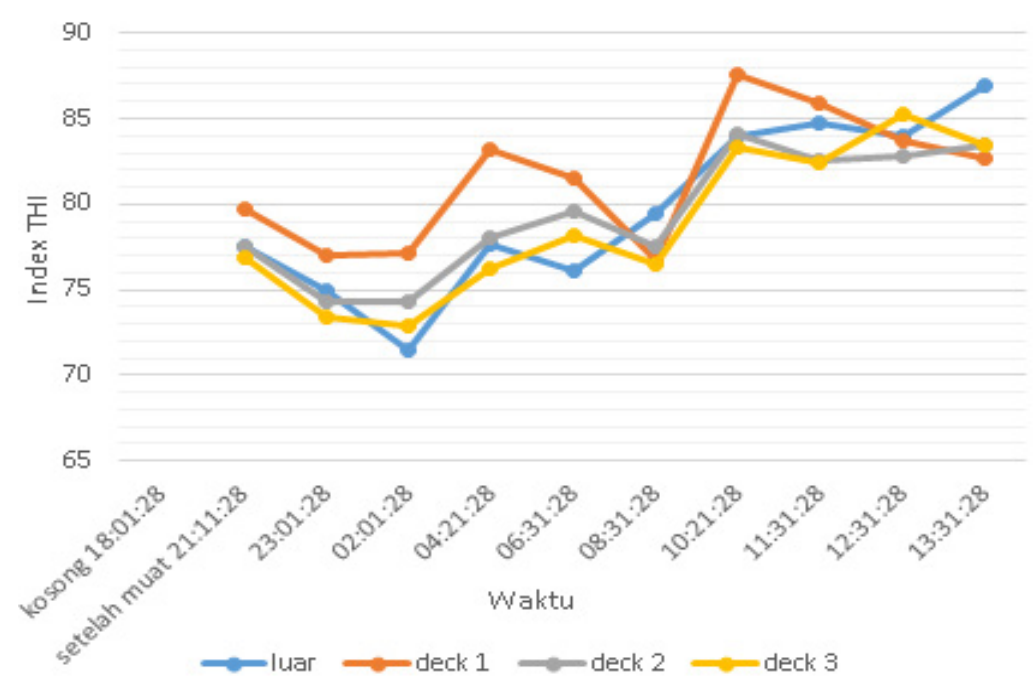

Gambar 2. Perubahan THI di luar dan di dalam deck pengangkut kambing

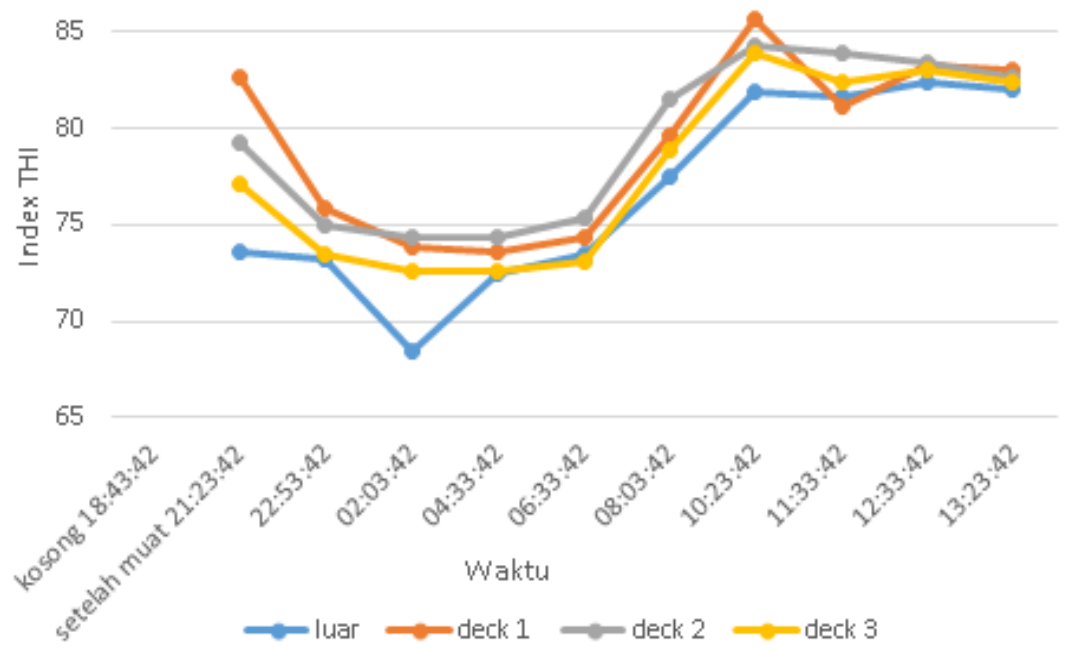

Gambar 3. Perubahan THI di luar dan di dalam deck pengangkut domba

yaitu $39.42 \pm 0.56{ }^{\circ} \mathrm{C}$ sebelum transportasi, dan $40.25 \pm$ $0.44{ }^{\circ} \mathrm{C}$ setelah transportasi. Suhu rektal normal kambing sekitar 38.6-40.2 ${ }^{\circ} \mathrm{C}$ (Suwignyo et al. 2016). Deck 1 mengalami peningkatan lebih tinggi $\left(1.50{ }^{\circ} \mathrm{C}\right)$. Hal ini diduga diakibatkan oleh nilai $T H I$ yang tinggi pada deck 1 . Nilai THI deck 1 di atas 78 baik pada perjalanan siang dan malam hari yang menandakan selama transportasi kambing mengalami cekaman ekstrim (Silanikove 2000), katagori bahaya (Hamdan et al. 2018), atau cekaman berat (Koluman dan Daskiran 2011). Peningkatan rataan suhu rektal setelah transportasi salah satunya diakibatkan oleh mikroklimatik dalam deck karena variasi perubahan suhu dan kelembapan mikro dapat mempengaruhi suhu rektal kambing (Ramadhan et al. 2017). Wilasari et al. (2019) menyatakan setelah 10 jam transportasi, kambing muda memiliki suhu rektal lebih tinggi $39.2^{\circ} \mathrm{C}$ dibanding kambing dewasa sebesar $39.0{ }^{\circ} \mathrm{C}$.

Posisi deck tidak berpengaruh signifikan $(\mathrm{P}>0.05)$ terhadap peningkatan suhu rektal domba. Hasil penelitian ini tidak jauh berbeda dengan transportasi 8 jam di
Kabupaten Bogor. Domba pada posisi berdiri sebelum transportasi memiliki suhu rektal $39.10{ }^{\circ} \mathrm{C}$ dan setelah transportasi meningkat menjadi $39.70{ }^{\circ} \mathrm{C}$ serta domba pada posisi berbaring sebelum transportasi 39.10 dan setelah transportasi naik menjadi $39.60{ }^{\circ} \mathrm{C}$ (Lendrawati et al. 2019). Rata-rata suhu rektal domba pada penelitian ini masih dalam kisaran normal yaitu $39.33 \pm 0.32{ }^{\circ} \mathrm{C}$ sebelum transportasi dan $39.81 \pm 0.31{ }^{\circ} \mathrm{C}$ setelah transportasi. Suhu rektal domba di daerah tropis berada pada $38.2-40{ }^{\circ} \mathrm{C}$ (Smith dan Mangkoewidjojo 1988) dan 38.37-38.64 ${ }^{\circ} \mathrm{C}$ (Nurmi 2016).

Ritme detak jantung. Hasil analisis menunjukan posisi deck tidak berpengaruh $(\mathrm{P}>0.05)$ terhadap perubahan ritme detak jantung kambing setelah transportasi. Ratarata ritme detak jantung kambing sebelum dan setelah transportasi pada penelitian ini masih pada kisaran normal, yaitu $100.71 \pm 21.18 \mathrm{kali}^{\text {menit }}{ }^{-1}$ sebelum transportasi dan $122.90 \pm 31.04$ kali menit $^{-1}$ setelah transportasi. Ritme detak jantung normal pada kambing adalah 70 sampai 135 kali menit $^{-1}$ (Frandson 1992). Peningkatan ritme detak jantung 
Tabel 1. Respon fisiologis dan penyusutan bobot badan kambing dan domba

\begin{tabular}{|c|c|c|c|}
\hline Parameter & Deck 1 & Deck 2 & Deck 3 \\
\hline \multicolumn{4}{|c|}{ Perubahan Suhu Rektal } \\
\hline $\begin{array}{l}\text { Kambing } \\
\left({ }^{\circ} \mathrm{C}\right)\end{array}$ & $1.50 \pm 1.00$ & $0.89 \pm 0.78$ & $0.36 \pm 0.52$ \\
\hline Domba $\left({ }^{\circ} \mathrm{C}\right)$ & $0.32 \pm 0.13$ & $0.36 \pm 0.25$ & $0.67 \pm 0.26$ \\
\hline \multicolumn{4}{|c|}{ Perubahan Detak Jantung } \\
\hline $\begin{array}{l}\text { Kambing } \\
\text { (kali } \\
\text { menit }^{-1} \text { ) }\end{array}$ & $32.40 \pm 29.36$ & $22.63 \pm 28.84$ & $43.15 \pm 25.89$ \\
\hline $\begin{array}{l}\text { Domba } \\
(\text { kali } \\
\left.\text { menit }^{-1}\right)\end{array}$ & $(22.67 \pm 5.5)$ & $(16.00 \pm 11.58)$ & $(11.6 \pm 10.33)$ \\
\hline \multicolumn{4}{|c|}{ Perubahan Laju Respirasi } \\
\hline $\begin{array}{l}\text { Kambing } \\
\text { (kali } \\
\text { menit }^{-1} \text { ) }\end{array}$ & $46.60 \pm 49.75$ & $47.39 \pm 19.31$ & $63.94 \pm 47.85$ \\
\hline $\begin{array}{l}\text { Domba } \\
(\text { kali } \\
\left.\text { menit }^{-1}\right)\end{array}$ & $(22.5 \pm 10.12)$ & $16.50 \pm 9.15$ & $24.40 \pm 9.32$ \\
\hline \multicolumn{4}{|c|}{ Penyusutan Bobot Badan } \\
\hline $\begin{array}{l}\text { Kambing } \\
(\%)\end{array}$ & $4.52 \pm 3.07$ & $4.52 \pm 2.90$ & $5.14 \pm 2.58$ \\
\hline Domba (\%) & $7.16 \pm 2.37$ & $7.18 \pm 2.22$ & $6.86 \pm 1.51$ \\
\hline
\end{tabular}

kemungkinan terjadi akibat perbedaan mikroklimatik sebelum transportasi (malam hari), selama transportasi, dan saat pengambilan data setelah transportasi (siang hari). Peningkatan ritme detak jantung yang tajam terjadi pada saat peningkatan suhu lingkungan (Edey 1983). Suhu dan kelembapan lingkungan yang tinggi menyebabkan detak jantung meningkat sebagai upaya ternak untuk dapat mengimbangi suhu lingkungan yang tinggi, sehingga suhu tubuh tetap dalam batas normal (Nurmi 2016).

Posisi deck tidak berpengaruh signifikan $(\mathrm{P}>0.05)$ terhadap perubahan ritme detak jantung domba. Ritme detak jantung domba pada seluruh deck menunjukan penurunan. Rataan ritme detak jantung sebelum transportasi melebihi kisaran normal detak jantung yaitu $83.00 \pm 12.72$ kali menit-1 dan setelah transportasi berada di bawah kisaran normal yaitu $69.00 \pm 7.99$ kali menit-1. Kisaran normal detak jantung pada domba adalah antara 70 hingga 80 kali tiap menit (Smith dan Mangkoewidjojo 1988). Penurunan ritme detak jantung diduga disebabkan oleh perbedaan mikroklimatik pada saat pengambilan data sebelum transpotrasi (siang hari) dan pengambilan data setelah transportasi (sore hari). Hal ini sesuai dengan penelitian Nelvita et al. (2018) bahwa penurunan detak jantung saat transportasi 97 kali menit-1 (diukur pada jam 13.00) dan 74 kali menit-1 (diukur pada jam 16.30).

Laju respirasi. Pengukuran laju respirasi dilakukan dengan menghitung siklus inspirasi dan ekspirasi dalam satuan waktu. Perubahan suhu selama transportasi mengakibatkan meningkatnya frekuensi nafas, denyut nadi dan suhu tubuh (Nelvita et al. 2018; Lendrawati et al. 2019). Frekuensi pernapasan yang normal kambing berkisar antara 20 sampai 25 kali per menit (Hafez 1968). Frekuensi pernafasan normal domba yaitu 15 sampai 25 kali menit $^{-1}$ (Smith dan Mangkowidjojo, 1988), 26 sampai 32 kali menit $^{-1}$ (Frandson 1992), 15 sampai 40 kali menit $^{-1}$ (Hecker 1983).

Hasil pengukuran laju respirasi pada kambing dan domba sebelum dan setelah transportasi berada diatas kisaran normal. Laju respirasi kambing $42.72 \pm 13.59$ kali menit $^{-1}$ sebelum transportasi dan $91.32 \pm 38.71$ kali menit $^{-1}$ setelah transportasi. Laju respirasi domba $66.39 \pm 16.68 \mathrm{kali}$ menit $^{-1}$ sebelum transportasi dan $73.23 \pm 10.57$ kali menit $^{-1}$ setelah transportasi. Hal ini menunjukan bahwa ternak telah mengalami cekaman pada sebelum transportasi. Cekaman yang timbul sebelum transportasi diakibatkan oleh faktor penangan ternak dan mikroklimat lingkungan. Penanganan ternak yang kurang baik bisa berakibat pada usaha ternak untuk melepaskan diri atau menghindar. Semakin tinggi tingkat kegiatan akan semakin besar panas yang dihasilkan dari metabolisme, di samping panas yang diperoleh dari metabolisme, tubuh ternak juga bisa memperoleh panas dari lingkungan (Sutedjo 2016) yang dapat dikeluarkan melalui proses repirasi.

Hasil analisis ragam menunjukan posisi deck tidak nyata mempengaruhi $(\mathrm{P}>0.05)$ perubahan laju respirasi kambing dan domba. Namun demikian, ditemukan peningkatan laju respirasi kambing pada semua deck, domba di deck 2 dan deck 3 serta terjadi penurunan pada domba di deck 1 . Hal ini diduga akibat jeda waktu pengukuran relatif lama pasca transportasi sehingga ternak telah mengalami adaptasi dan aklimatisasi yang direspon beragam oleh ternak dan ditunjukkan oleh nilai standar deviasi yang tinggi. Nelvita et al. (2018) melaporkan pada saat transportasi laju respirasi tercatat $47 \mathrm{kali}^{\mathrm{menit}}{ }^{-1}$ pada pengukuran pukul 10.00 meningkat menjadi 141 kali menit $^{-1}$ pada pengukuran pukul 13.00 , kemudian turun menjadi 30 kali menit $^{-1}$ pada pukul 16.30 dan naik kembali menjadi 33 kali menit $^{-1}$ pada pukul 19.00 .

Penyusutan bobot badan. Penyusutan bobot badan ternak merupakan kerugian yang paling nyata akibat transportasi karena berdampak langsung pada nilai ekonomi (Lendrawati et al. 2019). Hasil analisis ragam menunjukan deck tidak berpengaruh secara signifikan $(\mathrm{P}>0.05)$ terhadap persentase penyusutan bobot badan. Penyusutan bobot badan akibat transportasi kambing tercatat $4.73 \%$ lebih rendah dibandingkan dengan transportasi kambing selama 7 jam dengan jarak tempuh $300 \mathrm{~km}$. Kambing muda mengalami penyusutan bobot badan sebesar $6.67 \%$ dan pada kambing dewasa $4.92 \%$ (Gibran et al. 2015). Penyusutan bobot badan domba sebesar $7.06 \%$, Penyusutan ini lebih rendah bila dibandingkan dengan pengangkutan pada jarak $\pm 650 \mathrm{~km}$ selama \pm 30 jam dengan penyusutan bobot badan domba betina sebesar $2.6 \mathrm{~kg}$ atau sekitar $10.74 \%$, dan domba jantan sebesar $1.98 \mathrm{~kg}$ atau sekitar $8.18 \%$ (Baihaqi et al. 2011).

Perbedaan tingkat penyusutan kambing dan domba diduga diakibatkan karena waktu pengambilan data yang 
berbeda. Pengambilan data kambing sebelum dan sesudah transportasi lebih pendek \pm 18 jam, sedangkan jarak waktu pengukuran sebelum dan sesudah transportasi pada domba \pm 25 jam.

\section{Metabolit Darah}

Hasil evaluasi metabolit darah domba dan kambing disajikan pada Tabel 2. Hasil analisis ragam menunjukan posisi deck tidak berpengaruh signifikan $(\mathrm{P}>0.05)$ terhadap semua perubahan parameter metabolit darah yang diukur setelah transportasi.

Table 2. Perubahan konsentrasi glukosa, BUN dan kreatinin serum darah kambing dan domba setelah transportasi

\begin{tabular}{|c|c|c|c|}
\hline Parameter & Deck 1 & Deck 2 & Deck 3 \\
\hline \multicolumn{4}{|c|}{ Perubahan Glukosa Darah } \\
\hline $\begin{array}{l}\text { Kambing } \\
\left(\mathrm{mg} \mathrm{dl}^{-1}\right)\end{array}$ & $24.41 \pm 13.84$ & $18.15 \pm 9.94$ & $18.75 \pm 15.75$ \\
\hline $\begin{array}{l}\text { Domba } \\
\left(\mathrm{mg} \mathrm{dl}^{-1}\right)\end{array}$ & $33.63 \pm 21.99$ & $39.87 \pm 15.55$ & $35.91 \pm 18.57$ \\
\hline \multicolumn{4}{|c|}{ Perubahan $B U N$} \\
\hline $\begin{array}{l}\text { Kambing } \\
\left(\mathrm{mg} \mathrm{dl}^{-1}\right)\end{array}$ & $3.22 \pm 1.53$ & $4.71 \pm 2.51$ & $2.88 \pm 2.42$ \\
\hline $\begin{array}{l}\text { Domba } \\
\left(\mathrm{mg} \mathrm{dl}^{-1}\right)\end{array}$ & $3.20 \pm 4.38$ & $7.55 \pm 3.91$ & $2.38 \pm 1.63$ \\
\hline \multicolumn{4}{|c|}{ Perubahan Kreatinin Darah } \\
\hline $\begin{array}{l}\text { Kambing } \\
\left(\mathrm{mg} \mathrm{ml}^{-1}\right)\end{array}$ & $(0.022 \pm 0.017)$ & $(0.016 \pm 0.007)$ & $(0.016 \pm 0.016)$ \\
\hline $\begin{array}{l}\text { Domba } \\
\left(\mathrm{mg} \mathrm{ml}^{-1}\right)\end{array}$ & $(0.022 \pm 0.005)$ & $(0.008 \pm 0.006)$ & $(0.012 \pm 0.007)$ \\
\hline
\end{tabular}

(......) menunjukan penurunan antara sebelum dan setelah transportasi

Glukosa Darah. Peningkatan kadar glukosa darah pada ternak merupakan indikator metabolis terhadap stress (Lendrawati et al. 2019). Hasil evaluasi menujukan posisi deck tidak berpengaruh signifikan $(\mathrm{P}>0.05)$ terhadap perubahan konsentrasi glukosa darah kambing dan domba. Peningkatan glukosa dapat terjadi setelah ternak mendapat cekaman seperti transportasi. Transportasi tidak hanya mencakup tekanan fisik, tetapi juga tekanan emosional yang disebabkan oleh bongkar muat, kebisingan, getaran, dan gangguan sosial (Kannan et al. 2003). Cekaman transportasi telah dilaporkan menyebabkan peningkatan konsentrasi glukosa darah selama loading dan dua jam pertama transportasi, dan mulai menurun pada jam ke-3 dan kembali normal pada jam ke-18 (Kannan et al. 2000).

Hasil penelitian menunjukan peningkatan kadar glukosa darah kambing dan domba pada semua deck. Peningkatan konsentrasi glukosa darah terjadi karena pemecahan glikogen dari hati atau karena berkurangnya cadangan glikogen otot (Lendrawati et al. 2019). Peningkatan konsentrasi glukosa darah disebabkan oleh glikogenolisis yang terkait dengan peningkatan katekolamin dan glukokortikoid yang dilepaskan selama stres transportasi (Tadich et al. 2005). Hal yang hampir sama juga di ungkapkan oleh Anton et al. (2016) yang menyatakan ketika ternak menderita cekaman transportasi dan kekurangan pakan, maka sistem saraf pusat bekerja aktif dan memicu kerja hormon untuk pelepasan glukosa, sehingga terjadi peningkatan kadar glukosa dalam darah akibat terjadinya glikogenolisis yang terkait dengan peningkatan hormon katekolamin dan kortisol yang berada di bawah kendali saraf simpatik yang dilepaskan akibat cekaman.

Rata-rata konsentrasi glokosa darah kambing dan domba pada penelitian ini dalam katagori normal. Konsentrasi glukosa darah kambing $66.03 \pm 14.25 \mathrm{mg} \mathrm{dl}^{-1}$ sebelum transportasi dan $81.01 \pm 15.97 \mathrm{mg} \mathrm{dl}^{-1}$ setelah transportasi. Konsentrasi glukosa darah domba $44.44 \pm$ $14.85 \mathrm{mg} \mathrm{dl}^{-1}$ sebelum transportasi dan $80.72 \pm 16.26 \mathrm{mg}$ $\mathrm{dl}^{-1}$ setelah transportasi. Kadar glukosa darah kambing dan domba normal berkisar antara 34 sampai $84 \mathrm{mg}$ dl-1 (Panousis et al. 2012).

Blood Urea Nitrogen (BUN). Posisi deck tidak berpengaruh signifikan $(\mathrm{P}>0.05)$ tehadap perubahan konsentrasi $B U N$. Hasil evaluasi menunjukan rataan $B U N$ masih dalam kisaran normal. Rataan konsentrasi $B U N$ kambing penelitian ini adalah $20.70 \pm 4.84 \mathrm{mg} \mathrm{dl}^{-1}$ sebelum transportasi dan $22.62 \pm 2.45 \mathrm{mg} \mathrm{dl}^{-1}$ setelah transportasi. Rataan konsentrasi $B U N$ domba penelitian ini adalah 15.40 $\pm 2.34 \mathrm{mg} \mathrm{dl}^{-1}$ sebelum transportasi dan $20.04 \pm 3.29 \mathrm{mg}$ $\mathrm{dl}^{-1}$ setelah transportasi. Kadar urea darah normal pada kambing dan domba sehat berkisar antara 15.0 sampai 36.0 $\mathrm{mg} \mathrm{dl}^{-1}$ (Bendryman et al. 2000), 29.91 sampai $35.87 \mathrm{mg} \mathrm{dl}^{-1}$ (Rahayu et al. 2017).

Peningkatan kadar $B U N$ pasca transportasi dilaporkan oleh Kannan et al. (2000), Purbowati dan Purnomoadi (2005), Dalmau et al. (2014), dan Kassab dan Mohammed (2014). Peningkatan kadar $B U N$ akibat cekaman terjadi karena peningkatan aktivitas otot dan katabolisme protein yang dipicu oleh kekurangan pakan yang lama (Broom 2003; Dalmau et al. 2014). Pada saat kekurangan asupan nutrisi kandungan glukosa darah akan menurun maka glucagon akan disekresikan ke darah dari sel alpha pancreas, dampak dari tingginya glucagon dan ephinefrin di darah maka di hati akan terjadi gluconeogenesis dan di otot terjadi glikogenolisis (Astuti et al. 2014) urea merupakan hasil akhir dari glukoneogenesis protein yang tidak dimanfaatkan oleh tubuh ternak.

Kreatinin. Hasil analisis ragam menunjukan posisi deck tidak berpengaruh signifikan terhadap perubahan konsentrasi kreatinin darah, dan secara umum terjadi penurunan kadar kreatinin. Aktivitas fisik yang kuat seperti menggiring dan prosedur bongkar muat lebih berpengaruh terhadap aktivitas kreatinin pada kambing daripada perjalanan selama transportasi atau kekurangan pakan (Kannan et al. 2000). Dalmau et al. (2014) melaporkan terjadi penurunan yang tidak signifikan kadar kreatinin darah setelah transportasi domba durasi 24 jam.

Aktivitas kreatinin merupakan variabel penting yang mencerminkan cedera dan kelelahan fisik pada domba selama transportasi (Lendrawati et al. 2019). Lendrawati et al. (2019) juga mengatakan kreatinin merupakan hasil perombakan kreatinin fosfat yang dijadikan sebagai salah satu sumber energi ketika ternak mengalami stres, sehingga kadar kreatinin akan meningkat ketika ternak mengalami 
stres. Kreatinin merupakan zat yang mudah larut dan dieksresikan melalui urin, durasi perjalanan yang lama dan posisi berbaring selama transportasi diduga tidak menimbulkan pergerakan fisik dan cedera pada ternak, yang berakibat tidak terjadinya peningkatan kadar kreatinin darah.

Indikator respon fisiologis, penyusutan bobot badan dan metabolit darah menunjukan perubahan pada ternak kambing dan domba setelah transportasi namun masih dalam batas normal. Posisi deck tidak berpengaruh signifikan terhadap perubahan respon fisiologis, penyusutan bobot badan dan perubahan konsentrasi metabolit darah kambing dan domba yang ditransportasikan sejauh \pm 675 $\mathrm{km}$.

\section{KESIMPULAN}

Niliai THI disemua deck menunjukan kondisi mikroklimat yang menimbulkan cekaman ringan hingga berat pada saat transportasi. Posisi deck tidak berpengaruh signifikan terhadap perubahan respon fisiologis, penyusutan bobot badan dan perubahan konsentrasi metabolit darah kambing dan domba yang ditransportasikan dari Jawa Timur menuju Bogor-Jawa Barat.

\section{UCAPAN TERIMAKASIH}

Ucapkan terimakasih disampaikan pada Kementrian Riset dan Teknologi/BRIN yang telah mendanai pendidikan penulis melalui program beasiswa Saintek Kemenristek/ BRIN tahun 2018, kepada kawan-kawan di PT Agro Apis Palicio yang telah menyediakan waktu, tempat dan fasilitas penelitian, dan kepada Badan Pengkajian dan Penerapan Teknologi BPPT yang telah memberikan fasilitas dan izin studi.

\section{DAFTAR PUSTAKA}

Anton, A., L. M. Kasip, L. Wirapribadi, S. N. Depamede, \& A. R. S. Asih. 2016. Perubahan status fisiologis dan bobot badan sapi bali bibit yang diantarpulaukan dari pulau lombok ke kalimantan barat. JITPI. 2(1): 86-95

Bendryman, S. S., R. S. Wahyuni, \& H. Puspitawati. 2000. Pengaruh pemberian rimpang temulawak (Curcuma xanthorrhiza) dan temu hitam (Curcuma aeruginosa) dalam urea molasses blok (UMB) pada gambaran darah dan fungsi hati dan ginjal domba yang diinfeksi dengan cacing Haemonchus contortus. Vet Med J. 16(1): 1-8.

Baihaqi M., S. Rahayu, \& B. Romadhona. 2011. Lama rekondisi bobot badan domba ekor gemuk yang diberi ransum komplit pasca transportasi. Prosiding Workshop Nasional Diversifikasi Pangan Daging Ruminansia Kecil. Jakarta (ID): Kementerian Pertanian RI.

Broom, D. M. 2003. Transport stress in cattle and sheep with details of physiological and other indicators. Deutsche tierärztliche. Wochenschrift. 110: 83-89.

CATGP. 2017. Guide to good practices for the transport of sheep. Wageningen Livestock Research. Rev. 1; May 2018.

Costa, L. N. 2008. Short-term stress: the case of transport and slaugther. J Anim Sci. 8(1): 241-252.

Dalmau, A., A. D. Nardo, C. E. Realini, P. Rodríguez, P. Llonch, D. Temple, A. Velarde, D. Giansante, S. Messori, \& P.D. Villa. 2014. Effect of the duration of road transport on the physiology and meat quality of lambs. Anim Prod Sci. 54:179-186.

Dikmen, S., E. Alava, E. Pontes, J. M. Fear, B. Y. Dikmen, T. A. Olson, \& P. J. Hansen. 2008. Differences in thermoregulatory ability between slick-haired and wild-type lactating Holstein cows in response to acute heat stress. J Dairy Sci. 91: 3395-3402.

Edey, T. N. 1983. The Genetic pool of sheep and goats. Dalam: Goat and Sheep Production in The Tropics. ELBS. Longman Group Ltd, Essex.

Fazio, F., F. Arfuso, M. Rizzo, C. Giannetto, E. Giudice, Zanghìa, \& G. Piccione. 2018. Livestock handling and road transport influence some oxidative stress parameters in ewes. J Vet Behav. 26: 5-10.

Fisher, A. D., M. Stewart, D. M. Duganzich, J. Tacon, \& L. R. Matthews. 2004. The effects of stationary periods and external temperature and humidity on thermal stress conditions within sheep transport vehicles. N. Z. Vet J. 53(1): 6-9.

Frandson, R. D. 1992. Anatomi Fisiologi Ternak. Srigandono, Praseno K, penerjemah; Soedarsono, editor. Yogyakarta (ID). Gadjah Mada University Press. Terjemahan dari: Anatomy and physiology of farm animals.

Gasparesz, V. 1991. Teknik Analisis dalam Penelitian Percobaan. Bandung (ID). TARISTO.

Gibran, E. M. H., S. Dartosukarno, \& A. Purnomoadi. 2015. Pengaruh pemberian vitamin B kompleks terhadap penyusutan bobot badan akibat transportasi pada kambing kacang umur muda dan dewasa. Animal Agriculture Journal, 4(2):268-271.

Gonzaga dos Santos, A. C., M. Yamin, R. Priyanto, \& H. Maheshwari. 2019. Respon fisiologi domba pada sistem pemeliharaan dan pemberian jenis konsentrat berbeda. JIPTHP. 7(1): 1-9.

Hafez, E. S. E. 1968. Adaptation Of Domestic Animal. Philadelphia (US). Lea And Febriger.

Hamdan, A., B.P. Purwanto, D.A. Astuti, A. Atabany, \& E. Taufik. 2018. Respons kinerja produksi dan fisiologis kambing peranakan ettawa terhadap pemberian pakan tambahan dedak halus pada agroekosistem lahan kering di Kalimantan Selatan. JPPTP. 12(1): 73-84

Hecker, J. F. 1983. The Sheep as an Experimental Animal. London (UK): Academic Press.

Kannan. G, T. H. Terrill, B. Kouakou, O.S. Gazal, S. Gelaye, E. A. Amoah, \& S. Samaké. 2000. Transportation of goats: effects on physiological stress responses and live weight loss. J Anim Sci. 78: 14501457.

Kannan, G., B. Kouakou, T. H. Terrill, \& S. Gelaye. 2003. Endocrine, blood metabolite, and meat quality changes in goats as influenced by shortterm, preslaughter stress. J Anim Sci. 81: 1499-1507.

Kassab, A. Y., \& A. A. Mohammed. 2014. Ascorbic acid administration as anti-stress before transportation of 
sheep. Egyptian Journal Animal Production. 51(1)

KEMENTAN. 2014. Peraturan menteri pertanian republik indonesia nomor 114/Permentan/PD.410/9/2014 tentang pemotongan hewan kurban. Jakarta (ID): KEMENTAN.

Koluman, N, \& I. Daskiran. 2011. Effects of ventilation of the sheep house on heat stress, growth and thyroid hormones of lambs. Trop. Anim. Health Pro. 43: 11231127.

Lendrawati, R. Priyanto, M. Yamin, A. Jayanegara, W. Manalu, \& Desrial. 2019. Respon fisiologis dan penyusutan bobot badan domba lokal jantan terhadap transportasi dengan posisi berbeda dalam kendaraan. Jurnal Agripet. 19: 2.

Nelvita, T., A. Purnomoadi, \& E. Rianto. 2018. Pemulihan kondisi fisiologis, konsumsi pakan dan bobot badan domba ekor tipis pada umur muda dan dewasa pasca transportasi pada siang hari. JSPI.13: 4.

Nurmi, A. 2016. Respons fisiologis domba lokal dengan perbedaan waktu pemberian pakan dan panjang pemotongan bulu. Jurnal Eksakta. 1

Panousis, N., C. H. Brozos, I. Karagiannis, N. D. Giadini, S. Lafi, \& M. Kritsepi-Konstantinou. 2012. Evaluation of precision xceed Oे meter for on-site monitoring of blood b-hydroxybutyric acid and glucose concentrations in dairy sheep. Res Vet Sci. 9: 435-439.

Purbowati, E., \& A. Purnomoadi. 2005. Respon fisiologis domba lokal jantan pada rentang bobot hidup yang lebar akibat pengangkutan dari dataran tinggi ke dataran rendah. Seminar Nasional Teknologi Peternakan dan Veteriner.

Qisthon, A., \& M. Hartono. 2019. Respons fisiologis dan ketahanan panas kambing boerawa dan peranakan ettawa pada modifikasi iklim mikro kandang melalui pengkabutan. JIPT. 7(1): 206 - 211

Rahayu, S., M. Yamin, C. Sumantri, \& D. A. Astuti. 2017. Profil hematologi dan status metabolit darah domba garut yang diberi pakan limbah tauge pada pagi atau sore hari. Jurnal Veteriner. 18(1) : 38-45.
Ramadhan, A. F., S. Dartosukarno, \& A. Purnomoadi. 2017. Pengaruh pemberian vitamin b komplek terhadap pemulihan fisiologi, konsumsi pakan, dan bobot badan kambing kacang muda dan dewasa pasca transportasi. MEDIAGRO. 1313 (1): 23-33.

Sabarudin, A., E. R. N. Wulandari, \& H. Sulistyarti. 2012. Sequential injection-flow reversal mixing (sifrm)untuk penentuan kreatinin dalam urin. Jurnal MIPA 35(2):157-164.

Silanikove, N. 2000. Effects of heat stress on the welfare of extensively managed domestic ruminants. Lives Prod Sci. 67: 1-18.

Siregar, M. 2011. Transportasi dan Kaitannya dengan Hasil dan Kualitas Karkas. Medan (ID). Pusat kajian peternakan, perikanan, sumberdaya pesisir dan laut Fakultas Peternakan Universitas HKBP Nommenses.

Smith, J. B., \& S. Mangkoewidjojo. 1988. Pemeliharaan, Pembiakan dan Penggunaan Hewan Percobaan di Daerah Tropis. Jakarta.(ID). Universitas Indonesia Press.

Sutedjo H. 2016. Dampak fisiologis dari cekaman panas pada ternak. Jurnal Nukleus Peternakan. 3(1): 93-105.

Suwignyo, B., U. A. Wijaya, R. Indriani, A. Kurniawati, I. Widiyono, \& Sarmin. 2016. Konsumsi, kecernaan nutrien, perubahan berat badan dan status fisiologis kambing bligon jantan dengan pembatasan pakan. J Sain Veteriner. 34: 210-219.

Tadich, N., H. Gallo, H. Bustamante, M. Schwerter, \& G. van Schaik. 2005. Effects of transport and lairage time on some blood constituents of FriesianCross steers in Chile. J Livest Prod Sci. 93: 223-233

Thompson, I. M., \& G. E Dahl. 2012. Dry-period seasonal effects on the subsequent lactation. Professional Animal Scientists. 628-631.

Wilasari, B. A., E. Rianto, \& S. Mawati. 2019. Respon fisiologis dan lama pemulihan pada kambing kejobong jantan muda dan dewasa akibat transportasi. Prosiding Seminar Nasional Teknologi Peternakan dan Veteriner 2019. 